\title{
Food Security in India: Scientific Solutions and Apprehensions from Genetically Modified Crops
}

\author{
Ch. Sruthi ${ }^{1}$, CH. Srinivas ${ }^{2}$ and T. Ramesh ${ }^{3}$ \\ ${ }^{1}$ Research Scholar in Sociology, Department of Sociology, Kakatiya University, Warangal, India. \\ ${ }^{2}$ Department of Physics, University College of Science (Saifabad), Osmania University, Hyderabad, India. \\ ${ }^{3}$ Department of Sociology \& Social Work, UA\&SC, Subedari, Kakatiya University, Warangal, India.
}

\begin{abstract}
India is at crossroads as far as food security is concerned. The mode of production can be galvanized by adopting the modern technology like GMO at one hand with utmost care render to safe guard the environment. On the other hand there is a need to improve the food distribution mechanism with current modern management techniques. The present article deals with the needed facets of Food Security and GMO crops and their pros and cons.
\end{abstract}

Keywords- Agricultural Transformation Centers, Climate-Resilient Agriculture, Food Security, Genetically Modified Crops (GMC), Genetically Modified Organisms (GMO), Malnutrition, etc.,

\section{Introduction}

Food Security is a measure of ensured access to essential nutrition. It refers to a household's or country's ability to provide future physical and economic access to sufficient, safe, and nutritious food that fulfills the dietary needs and food preferences for living an active and healthy lifestyle [1]. The World Health Organization (WHO) defines three facets of food security as Food availability, Food access, and Food use. Food availability is having sufficient quantities of food on a consistent basis, where as Food access is having sufficient resources, both Economic and Physical, to obtain appropriate foods for a nutritious diet. Food use is the appropriate use based on knowledge of basic nutrition and care, as well as adequate water and sanitation.

The Food and Agriculture Organization of United Nations (FAO) has added a fourth facet as the stability of the first three dimensions of food security over time [1]. Malnutrition is nothing new for many Indians. As per International Food Policy Research Institute's 2011 Global Hunger Index, about 60 million children in India are underweight and malnourished, while $21 \%$ of the population as a whole in general is malnourished. According to a report by the World Bank, productivity losses in India due to stunted growth, iodine deficiencies, and iron deficiencies are equivalent to almost $3 \%$ of GDP. While during the colonial era famine was the primary result of "food insecurity", now malnutrition has replaced it.

In a country where millions go hungry every day and where food prices are breaking the back of the common man, a bumper harvest is rotting in go-downs a shocking truth found by the correspondents of Head lines Today. But the government plans to increase procurement and has also disallowed exports to meet the projected requirement of grain under the proposed Food Security Act, instead of solving the problems strategically straighter manner [2].

Genetically-modified foods have the potential to solve many of the world's hunger and malnutrition problems, and to help protect and preserve the environment by increasing yield and reducing reliance upon chemical pesticides and herbicides. Now, Genetic Engineering is the inevitable wave of the future and that we cannot afford to ignore a technology that has such enormous potential benefits. However, we must proceed with caution to avoid causing unintended harm to human health and the environment as a result of our enthusiasm for this powerful technology.

\section{Food Security - Government Scenario}

The last great famine in India occurred in 1943, and served as a case study for Amartya Sen, in his ground breaking work "Poverty and Famines", in which he showed that famine was rarely the result of lack of food, but was rather the result of intervening economic factors, such as unemployment, declining wages and, poor food distribution systems in India. The current food insecurity of India lies in poor food supply chain mechanism.

The bumper rot is in-spite of the Supreme Court's directive (2010) to the centre to ensure free distribution of food grains to the hungry poor of the country instead of allowing it to rot in the FCI go-downs. The alarming situation can be understood from the statement of former CMD of Food Corporation of India (FCI), Mr. Alok Sinha as, "The inflow - outflow management of the FCI is not good. I don't know what is 
government's plan is, but we should either export the food grain or go to common man with the Food Security Act"[3]. Even, if a small amount of food grain is wasted, this is nothing short of crime. Instead of letting it rot, we should export it.

A positive note is that Government of India is expected to remain self sufficient in production of food staples until at least 2025. The Central Government is attempting to rectify the problem of malnutrition with its National Food Security Bill - 2013, which was introduced to provide for food and nutritional security in human life cycle approach, by ensuring access to adequate quantity of quality food at affordable prices to the people to live a life with dignity and for matters connected therewith or incidental thereto. Rather than correcting supply chain issues, which increases the availability of food at reduced costs, the government has chosen to subsidize grain purchases. In addition, the government is doing this at a time when it can ill afford the expense associated with underwritten grain purchases for almost two thirds of the country's population.

It's likely that continued government subsidies has contained in the food bill, will only lead to further market distortions. Absence of legislative progress and further market liberalization, market distortions, along with vested interests by middlemen in perpetuating the existing lengthy supply chains, will continue to plague the population of India for some time. The result of this grim situation will surely be a continuation of the ongoing malnutrition epidemic, which will continue to handicap an already slowing economy.

\subsection{Reasons for Food Insecurity}

Insufficient allocation of funds in National and State budgets to guarantee food security. The government is lacking a clear and strategic plan with specific provision of funds in the budget to deal issues like fertilizers, seeds and water facilities. As far as Agricultural Development is concerned much of the funds are being provided by the central government in national budget and the contribution of the state government is very less and sometimes even nothing.

In 2012-13 Budget Rs.1,550 Corers were allotted to agricultural sector by the Central Government which if distributed among all the states each state gets Rs. 100 Crore, which are very less to deal with the related issues of agriculture. Presently 58\% of population is employed in the agricultural sector, but the allocation of funds in the budget is not in proportion to this. This year the production of food grains is 25 Corer tons and in the next coming 8 years the requirement would be nearly 30 Crore tons, but unfortunately there has been no strategic improvement in the allocation of funds to increase the production. The schemes such as NREG has not only increased the agricultural labour cost but also made it difficult for the farmer to get agricultural labours who play an important role in production, which resulted in increased cost of production. The situation becomes still worse when the farmers are not being provided with minimum floor price for their crops , leading to farmer's suicides.

The government has to justify itself regarding the essentiality of spending crores of rupees towards schemes such as providing subsidized rice (i.e., one rupee per $\mathrm{kg}$ ) for maintaining their vote bank or to provide reasonable floor price for the farmers for their crops, which is very important to maintain their spirit of cultivation. The government is also neglecting the role of Agricultural Research Universities in increasing the agricultural production and educating the farmers regarding various new technologies.

The Central Government has been claiming of allocating Rs.2,250 Crores towards NATIONAL FOOD SECURITY MANAGEMENT (NFSM), i.e., each state gets not even Rs. 100 Crore and it has been claimed that this funds are meant for the encouragement of the extension of productive area as far as rice, wheat, pulses are concerned, but in reality most of the farmers are shifting to Bt. cotton from pulse cultivation due to the lack of proper price support from the government. Apart from this, the government is providing very less funds towards Veterinary maintenance of Cattle which would be approximately Rs. 3 per cattle per annum.

The alarming threat to food security is improper food chain supply, much of the food grains are getting rotten in the godowns due to the lack of proper food supply scheme with the government. Much could be done to tackle the problem of food security without going for GM Food, if the political will is not lacking.

\section{Genetically Modified Technology}

Genetic Modification also known as Genetic Engineering or Recombinant DNA Technology, was first applied in 1970's. This technique allows selected individual genes to be transferred from one organism into another and also between unrelated species. It is one of the methods used to introduce novel traits or characteristics into micro-organisms, plants and animals. The products obtained from this technology are commonly called Genetically Modified Organisms (GMOs). GMOs are officially defined in the $\boldsymbol{E} \boldsymbol{U}$ legislation as "Organisms in which the genetic material (DNA) has been altered in a way that does not occur naturally by mating and/or recombination."

Genetic techniques could include :

- Transferring genes from one organisms to another

- Moving, deleting, modifying, or multiplying genes within a living organism 
- Modifying existing genes or constructing new ones, and incorporating them into a new organism

\subsection{Pros of GM Crops}

The world population has topped 6 billion people and is predicted to double in the next 50 years. Ensuring an adequate food supply for this booming population is going to be a major challenge in the years to come. GM foods promise to meet this need in a number of ways :

(i) Pest resistance : These GM crops reduces the usage of pesticides thereby reducing the potential health hazards and also the environmental harms caused due to the excessive usage of pesticides and also reduces the cost of bringing crop to the market $[4,5]$.

(ii) Herbicide tolerance : Crop plants genetically - engineered to be resistant to a powerful herbicide could prevent environmental damage by reducing the amount of herbicide needed, reduces the cost of the crop and also saves time [6].

(iii) Disease resistant : There are many viruses, fungi and bacteria that cause plant diseases. Plant biologists are working to create plants with genetically-engineered resistance to these diseases [7,8].

(iv) Cold tolerance : Unexpected frost can destroy sensitive seedlings[9]. An antifreeze gene from cold water fish has been introduced into plants, that able the plants to tolerate cold temperatures.

(v) Drought tolerance / salinity tolerance : Creating plants that can withstand long periods of drought or high salt content in soil and groundwater will help people to grow crops in formerly inhospitable places $[10,11]$.

(vi) Nutrition : Malnutrition is common in third world countries where people rely on a single crop such as rice for the main staple food of their diet. Since rice doesnot contain adequate amounts of all necessary nutrients to prevent malnutrition, If rice could be genetically engineered to contain additional vitamins and minerals, nutrient deficiencies could be alleviated $[12,13,14]$.

(vii) Pharmaceuticals : Medicines and vaccines are often costly to produce and require some storage conditions which are not readily available in third world countries. Researchers are working to develop edible vaccines in tomatoes and potatoes[15,16], which will be easier to ship store and administer than traditional injectable vaccines.

(viii) Phytoremediation : These GM plants are not grown as crops. Soil and ground water pollution continues to be the problem of all parts of the world. Plants such as poplar trees have been genetically engineered to clean up heavy metal pollution from contaminated soil [17].

\subsection{Potential Cons of GM Crops - Solutions}

Food and agricultural biotechnology has evoked strong opposition, the fears relate to bio-safety and environmental safety, adverse impact on biodiversity and long term impact on human and animal health. The controversy relating to Bt-brinjal and moratorium on its release imposed by the then Minister for Environment and Forests, serve as a wakeup call. The Hon'ble Supreme court of India has also raised several issues of public importance with reference to genetically modified crops and foods. Several states have imposed a ban on the testing of GMOs. The Kerala Government has not allowed even the testing of genetically modified Rubber, although we need urgently rubber clones tolerant to high temperature.

Agribusiness was criticized of pursuing profits without any concern for potential hazards, and even the government was criticized for inadequate Regulatory Body by the environmental activists, religious organizations, public interest groups, professional associations, other scientist and government officials. It has been identified the three potential hazards of GM foods, they are

\section{Environmental hazards :}

- Unintended harm to other organisms.

As per a Laboratory study published in Nature [18] showed that the pollen from Bt. Corn caused high mortality rates in monarch butterfly caterpillars, which could eat the pollen and perish. Though the study was not conducted under natural fields conditions, the results seemed to support the viewpoint. Unfortunately Bt. toxin kill many species of insect larvae indiscriminately, it is not possible to design $\mathrm{Bt}$ toxins that would kill only crop-damaging pests and remain harmless to other insects. The topic is subject to debate after being reexamined by United States Department of Agriculture (USDA) and United States of Environmental Protection Agency (USEPA).

- $\quad$ Reduced effectiveness of pesticides.

Just as some population of mosquitoes developed resistance to DDT, many people are concerned that insects will become resistant to Bt. or other crops that have genetically modified to produce their own pests.

- Gene transfer to non-target species. 
Another concern is that crop plants engineered for herbicide tolerance weeds will cross-breed, resulting in the transfer of the herbicide resistance genes from the crops into the weeds. These "Super Weeds" would then be herbicide tolerant as well. Other introduced genes may cross over into non-modified crops plants next to GM crops. This was shown in defense by farmers against lawsuits filed by Mansanto.

\section{Human health risks:}

- Allergenicity : There is a possibility of introducing a new gene into a plant may create a new allergen or cause an allergic reaction [19] in susceptible individuals. Which happened to many children in US and Europe who developed life threatening allergies to peanuts and otherfoods?

Hence extensive testing of GM foods may be required to avoid the possibility of harm to consumers with food allergies.

- Unknown effects on human health: There is a growing concern that introducing foreign genes into food plants may have an unexpected and negative impact on human health, though scientists believe that GM foods do not present a risk to human health [20,21, 22].

\section{Economic concern :}

Bringing a GM food to market is a lengthy and costly process, and of course agro-biotech companies wish to ensure a profitable return on their investment. Patent infringement is a big concern of agribusiness, which raises the price of seeds so high that small farmers and third world countries will not be able to afford seeds for GM crops, thus leading to trickledown effect.

Patent infringement lead to the introduction of "Suicide Gene" in the GM plants. That is these plants would be viable only for one growing season and would produce sterile seeds that do not germinate. Farmers need to buy a fresh supply of seeds each year. Which would be financially disasterous to farmers of third world countries who cannot afford, who traditionally set aside a portion of their harvest to plant in the next growing season. However, in an open letter to public, Monsanto has pledged to abandon all research using this suicide gene technology [23].

There are several solutions to the three problems mentioned above. Genes are exchanged between plants via pollen. Two ways to ensure that non-target species will not receive introduced genes from GM plant are to create GM plants that are male sterile (do not produce pollen) or to modify the GM plant so that the does not contain the introduced gene [24,25,26]. Cross pollination would not occur, and if harmless insects such as monarch caterpillars were to eat pollen from GM plants , the caterpillars would survive.

Another possible solution is to create buffer zones around fields of GM crops [27,28,29]. That is non-GM crops would be planted to surround a field of Bt. GM Corn, and the non-GM Corn would not be harvested. Beneficial or harmful insects would have refuge in the non-GM corn, and insect pest would be allowed to destroy the non-GM corn and would not develop resistance to Bt. pesticides. Gene transfer to weeds and other crops would not occur as the pollen blown by would not travel beyond the buffer zone. Necessary estimates of the width of the buffer zone are required [30] and may not be feasible if too much of acreage is required for buffer zone.

\section{Conclusion}

The alarming threat to food security is due to improper food chain supply, the Government should utilize the expertise of Western big-boxes like Wal-Mart and Carrefour into the retail sector in supply chain management, and the influx of desperately needed fresh thinking and innovation into agricultural and food supply business would have expedited changes downstream, helping alleviate malnutrition.

To improve the food security, the following measure are inevitable,

1. The attention should be given to Climate - resilient Agriculture. In dry farming areas, methods of rainwater harvesting and storage, aquifer recharge and water shed management as well as improvement of soil physics, chemistry and microbiology needs to be spread widely. The cultivation of fertilizer trees can enrich the soil fertility and help to improve soil carbon sequestration and storage can be promoted under the Green India Mission as well as MGNREGA. A few fertilizer trees and a biogas plant in every field will help to improve enormously the productivity and profitability of dry land farming. In addition, it may contribute to climate change mitigation.

2. Obviously powerful innovations like genetic modification require professionally-led regulatory structures. The Government of India has developed, a much needed, Biotechnology Regulatory Authority Act for being discussed in Parliament. The aim of the Act is to provide a professional and transparent Regulatory Body which can inspire public, political, professional and media confidence. It should be realized as early as possible. Apart from this, The Department of Biotechnology has initiated a program for organizing DNA Clubs in Schools to familiarize the young scholars with implications of human genome, rice genome, genetic modification and other aspects of food security and human wellbeing, which helps to promote 
critical understanding of the enormous progress made in Genome Analysis and Molecular-Mapping with reference to their implications for food and nutrition, security and public health.

3. Need for Setting up Agricultural Transformations Centre

Government of India, a few years ago, has launched a programme for enabling the farm graduates to start agri-clinics and agri-business centres, it at that time failed to attract the interest of educated youth. Now ,it is time that the programme be restructured and the agricultural universities be encouraged to motivate farm graduates and play a key role in the agriculture and rural development. Ideally, a group of four to five men and women farm graduates, who have specialized in agriculture, fisheries, agri-business and home science, could jointly launch an agri-clinic cum agri-based centre in every block. Agri-clinics will provide the services needed during the production phase of farming such as integrated pest management, while agri-business centre will cater to the needs of farm families during the post harvest phase of agriculture. Thus, farm women and men can be assisted during the entire crop cycle. Such an integrated centre can be termed as "Agriculture Transformation Centre" its major role will be launching of Small Farm Management Revolution.

\section{References}

[1] Food and Agriculture Organization of United Nations (FAO), Agricultural and Development Economics Division, June 2006

[2] "Food grains production..", Inside Story, Headline Today, $22^{\text {nd }}$ June, 2011

[3] “Food grains rot..", Headline Today, $22^{\text {nd }}$ June, 2011.

[4] "Insecticidal proteins from Bacillus thuringiensis protect corn from corn rootworms", Nature Biotechnology, Vol 19, No 7, pp 668-672, July, 2001.

[5] "Lepidopteran-resistant transgenic plants", US Patent 6313378, Nov 2001, Monsanto.

[6] "The use of cytochrome P450 genes to introduce herbicide tolerance in crops: a review", Pesticide Science, Vol. 55, No 9, pp 867874, Sept., 1999.

[7] "Transgenic Approaches to Combat Fusarium Head Blight in Wheat and Barley", Crop Science, Vol. 41, No 3, pp 628-627, Jun 2001.

[8] "Post-transcriptional gene silencing in plum pox virus resistant transgenic European plum containing the plum pox potyvirus coat protein gene", Transgenic Research, Vol. 10, No 3, pp 201-209, Jun 2001.

[9] "Type II fish antifreeze protein accumulation in transgenic tobacco does not confer frost resistance", Transgenic Research, Vol. 8, No 2, pp 105-117, Apr 1999.

[10] "Transgenic salt-tolerant tomato plants accumulate salt in foliage but not in fruit", Nature Biotechnology, Vol. 19, No 8, pp 765768, Aug 2001.

[11] "Peroxidase activity of desiccation-tolerant loblolly pine somatic embryos", In Vitro Cellular \& Developmental Biology Plant, Vol. 36, No 6, pp. 488-491, Dec 2000.

[12] "Genetic engineering towards carotene biosynthesis in endosperm", Swiss Federal Institute of Technology Institute for Plant Sciences.

[13] "New rice may help address vitamin A- and iron deficiency, major causes of death in the developing world", Rockefeller Foundation.

[14] "Rice Biotechnology: Rockefeller to End Network After 15 Years of Success", Science, Vol. 286, No 5444, pp 1468-1469, Nov 1999.

[15] "Medical molecular farming: production of antibodies, biopharmaceuticals and edible vaccines in plants", Trends in Plant Science, Vol. 6, No 5, pp 219-226, May 2001.

[16] "Oral immunization with hepatitis B surface antigen expressed in transgenic plants", Proceedings of the National Academy of Sciences, USA, Vol. 98, No 20, pp. 11539-11544, Sep 2001.

[17] "Phytodetoxification of hazardous organomercurials by genetically engineered plants", Nature Biotechnology, Vol. 18, No 2, pp. 213-217, Feb 2000.

[18] "Transgenic pollen harms monarch larvae", Nature, Vol. 399, No 6733, p 214, May 1999.

[19] "Identification of a Brazil-nut allergen in transgenic soybeans", New England Journal of Medicine, Vol. 334, No 11, pp 688-692, 1996.

[20] "Effect of diets containing genetically modified potatoes expressing Galanthus nivalis lectin on rat small intestine", Lancet, Vol. 354, No 9187, pp 1353-1354, Oct 1999.

[21] "Safety of genetically modified food questioned: Interview with gene Scientist", Dr Arpad Pusztai, (http://www.wsws.org/articles/1999/jun1999/gmo-j03.shtml ).

[22] "The Lancet scolded over Pusztai paper", Science, Vol. 286, p 656, Oct 1999.

[23] "In an open letter from Monsanto CEO Robert B. Shapiro to Rockefeller Foundation President Gordon Conway", Monsanto announced it will not pursue technologies that render seed sterile. (http://www.monsanto.com/monsanto/gurt/default.htm)

[24] "New tools for chloroplast genetic engineering", Nature Biotechnology, Vol. 17, No 9, pp 855-856, Sep 1999.

[25] "Tandem constructs: preventing the rise of superweeds", Trends in Biotechnology, Vol. 17, No 9, pp 361-366, Sep 1999.

[26] "Containment of herbicide resistance through genetic engineering of the chloroplast genome", Nature Biotechnology, Vol. 16, No 4, pp 345-348, Apr 1998.

[27] "Efforts to bioengineer intrinsic resistance to insect pests into crop plants have made use of a natural bacterial toxin, Bt, from Bacillus thuringiensis Berliner", Science, Vol. 284, No 5416, p 873, May 1999.

[28] "Inheritance of Resistance to Bacillus thuringiensis Toxin (Dipel ES) in the European Corn Borer", Science, Vol. 284, No 5416, pp 965-967, May 1999.

[29] "Buffers urged around Bt corn fields", Environmental News Network, http://www.enn.com/enn-newsarchive/1999/07/071499/btbuffer_4342.asp

[30] "GM crops: public perception and scientific solutions", Trends in Plant Science, Vol. 4, No 12, pp 467-469, Dec 1999. 